\title{
Az értelmileg és halmozottan sérült felnőttek normalizációs életesélyei intézményi környezetben
}

\author{
Fucskó Mónika
}

doktorandusz, főiskolai tanársegéd, Debreceni Egyetem Egészségügyi Kar Szociális és Társadalomtudományi Intézet Szociális Munka Tanszék, 4400 Nyíregyháza, Sóstói út 2-4.

\section{INFO ABSTRACT}

\author{
Mónika Fucskó \\ fucsko.monika@foh.unideb.hu
}

The normalization chances of adults with mental and cumulative disabilities in institutions. The central theme of the research is: Assessment of the quality of life of individuals with intellectually and cumulatively impaired lives, their normalization possibilities with special regard to live independent life in Nyíregyháza - in various maintained social institutions (nursing home care and home care). Making comparison between those who live together with the family in day-care providers and the life of people who completely live an independent life. The focus of my research are on intelligently and cumulatively injured adults who, as a result of their state, spend their everyday's lives in a social institution. The central area of the investigation is primarily the possibility of obtaining and preserving independent autonomous lifestyles within the nursing care institution's and home-country settings. Another important question of the research is the existence or lack of autonomous decisionmaking in the world of everyday life. The main focus is on the possibilities of the special organizational structure for adult people with intellectual impairments, their ability how to control their lives, the independence of the institution, and whether there are differences in the two very distinctive types of specialized care. Another question is whether the operation of various maintained (church, civil, state) institutions is similar or different in relation to the issue that was examined.

Principle of Normalization As the Subject of the Test: The principle requires that every person with intellectual disabilities should have access to living conditions and quality of life that meet the conditions and lifestyle of the society as usual and accepted as possible. 


Kulcsszavak:
értelmi fogyatékosság,
életminőség,
normalizáció,
esélyegyenlőség

Ez a tanulmány a XI. Nyíregyházi Doktorandusz Konferencián (2017. 12. 01., Nyíregyházi Egyetem) elhangzott előadás alapján készült.

\begin{abstract}
Absztrakt. A kutatás központi témája: Értelmileg és halmozottan sérült felnőttek életminőség vizsgálata, normalizációs életlehetőségei, különös tekintettel az önálló életvitelre, Nyíregyháza - különböző fenntartásban lévő- szociális intézményeiben (ápoló-gondozó otthoni, lakóotthoni vizsgálat keretében). Összehasonlítás végzése a családban élő - nappali ellátást igénybe vevő-, valamint a teljesen önálló életvitelt folytató sérült emberek életvitelével. Kutatásom fókuszában elsősorban az értelmileg és halmozottan sérült felnőtt személyek állnak, akik állapotukból adódóan szociális intézményi keretek között töltik mindennapjaikat. A vizsgálat központi területe elsődlegesen az önálló autonóm életvitel megszerzésének és megőrzésének lehetőségei az ápoló-gondozó intézményi és lakóotthoni keretek között. Lényeges kutatási kérdés továbbá az önálló döntéshozatal megléte, vagy hiánya a mindennapok világában. A hangsúly föként az, hogy a sajátságos szervezeti struktúra milyen lehetőségeket teremt az értelmi sérüléssel küzdő felnőtt emberek számára, mennyire van lehetőségük saját maguknak irányítaniuk életüket, mennyire enged önállósodni az intézmény, illetve, hogy van-e különbség a szakosított ellátás két igen jellegzetes típusának ellátásában. További kérdés, hogy a különböző fenntartásban lévő (egyházi, civil, állami) intézmények müködése mutat-e hasonlóságot, illetve különbözőséget a vizsgált kérdéssel kapcsolatosan.

A normalizációs alapelv, mint a vizsgálat tárgya: Az alapelv szerint minden értelmileg sérült személy számára olyan életfeltételeket és életminőséget kell elérhetővé tenni, melyek a társadalom által megszokott és elfogadott feltételeknek és életmódnak a lehetőség szerinti legnagyobb mértékben megfelelnek.
\end{abstract}

\section{Bevezetés}

A szociális gondoskodás modelljei az elmúlt évtizedek során komoly átalakuláson mentek keresztül. A második világháborút követően az elsősorban a jóléti kiadásokat előnyben részesítő „gondoskodó állam” az idő elteltével és a körülmények változásával át kell, hogy alakuljon ,,aktiváló” majd „befektető” állammá (Esping-Andersen, 1990).

A XX. század végére már megkérdőjeleződik a jóléti állam müködése, vajon be tudja-e tölteni alapvető funkcióját? Reformokra van szükség az intézményrendszerét és a szociális jogokat tekintve. A változó tényezők, mint az elöregedő társadalom, az alacsony születésszám, a nemek közötti szerepek változásai, az átalakuló családszer- 
kezet újfajta kihívásokat és egyenlötlenségeket teremt. Erre válaszként kezd kialakulni az ,aktiváló állam”, melynek fö szerepe az állampolgárok aktiválása. Az újfajta elgondolást sok kritika is éri, ugyanakkor többen úgy gondolják, hogy aktiválás révén lehet az állampolgárok függőségét csökkenteni. Mead szerint az inklúzív társadalom az, amelyben a polgárok megfelelően tudnak müködni (Mead, 1986).

Az ezredfordulón a társadalmi befektetés modell kerül elötérbe, amelyben a hangsúly a prevención van, a hátrányos helyzetü, vagy azzal veszélyeztetett társadalmi csoportokat igyekszik felkészíteni a kockázatok elkerülésére. Ezért itt elötérbe kerül például a korai felismerés és fejlesztés, a gyermekek napközbeni ellátásának megszervezése a nők munkába állásának lehetősége érdekében, valamint az ifjúságpolitika a fiatalok leszakadásának elkerülése érdekében (pl.: felnőttképzési programok) (Csoba, 2017).

Az előbbiekben említett rövid összefoglalóban már jól látható az a fajta út, amit a jóléti állam vállal az ellátások és garantált minimumok biztosítása érdekében, és azért, hogy a leszakadó társadalmi csoportok is képesek legyenek a kihívásoknak megfelelni.

Amennyiben leszakadó csoportokról beszélünk mindenképpen érdemes megvizsgálni az egyik legnehezebb helyzetben lévő, igen nagy létszámú (megközelítőleg a lakosság 4,9\%-a) csoport - fogyatékkal élők - helyzetét. A fogyatékos személyek esetében szinte kivétel nélkül elmondható, hogy mások támogatása, segítsége nélkül még ha ez minimális mértékü is- képtelenek a mindennapokban boldogulni, életvitelüket megfelelö szinten folytatni.

Tanulmányomban ezért szeretnék röviden összefoglalni, vázolni néhány támogatási rendszert, szociálpolitikai ellátást, amelyek az elmúlt évtizedek során lehetőséget biztosítottak ezen személyek számára a „normalizációs életminta” eléréséhez.

\section{A kutatás alapkérdései}

\section{A fogyatékosság, mint hátrány}

Kiindulópontként fontos meghatározni, hogy maga a fogyatékosság mit is jelenthet, mikor mondhatjuk, hogy valaki fogyatékos, hiányt szenved valamiben, az állapotából adódóan.

Mindenképpen az egészséget és a tökéletességet kellene figyelembe vennünk, ha hátrányokról, hiányokról, más állapotról akarunk véleményt alkotni. Ebből a szempontból fontos bizonyos fokozatosságot felállítani, attól függően, ki milyen mértékben egészséges, vagy éppen beteg, vagy fogyatékos. A társadalmi felfogás abból indul ki, hogy van egy határvonal, az egészséges, ép személyek és a határvonalon túli valamilyen formában nem egészségesek, sőt korlátozottak között. A határvonal meghúzása nem egyszerü feladat, sokszor nem is egyformán húzódik meg a különböző országok tekintetében. Befolyásolhatják minősítések, orvosi besorolások, kategóriák, különböző szabályozások.

A hátrányos helyzet meghatározása szempontjából általánosságban a betegséget mely gyógyítható, amiből fel lehet épülni - nem szokták ide sorolni. Ez esetlegesen 
csak egy átmeneti időre szóló állapot. Tartós, társadalmi hátrányként azokat az egészségkárosodásokat nevezzük, melyek:

- a krónikus, gyógyíthatatlan betegség kategóriájába,

- az egészségkárosodások kategóriájába,

- vagy a fogyatékosság kategóriájába tartoznak.

A fogyatékosságot további három kategóriába sorolhatjuk be, különböző megközelítések alapján:

1. sérültség (impairment), a testi funkciók korlátozottsága,

2. fogyatékosság (disability), a tevékenységek akadályozottsága,

3. rokkantság (handicap), a társadalmi életben fellépő korlátozottság.

Az akadályozottság, korlátozottság ilyen szempontú besorolása akár bizonyos funkciókra is vonatkozhat, mint a munkaképesség csökkenése, vagy akár a tanulási képességek csökkenése. A fogalmak rendszerében olykor nem egyszerü eligazodni, de az bizonyos, hogy határvonal húzódik az épek és az akadályozott személyek között. Így alakulhat ki az épek és a fogyatékkal élők kategóriája. A fogyatékosság azonban nem pusztán abból a tényből fakadóan okoz hátrányt, amely magából az állapotból adódik, hanem az egyén társadalomban betöltött szerepek, a társadalmi részvétel tekintetében. Ebből kiindulva ezek a korlátozottságok behatárolják, hogy az adott állapotú - fogyatékos - személy, milyen:

- iskolába járhat, milyen szakmát tanulhat,

- milyen munkát vállalhat, milyen munkakörökben,

- milyenek lehetnek az egyéb tevékenységei, mint a szabadidő eltöltése, a sport tevékenységben való részvétele, hol szórakozhat stb,

- hol élheti mindennapjait, hol lakhat.

Ezekből a lehetőségekből, vagy éppen ezek korlátaiból adódóan nem maga a fogyatékos állapot lesz a hátrány, hanem azok a szerepek, szabályok, amelyek behatárolják a fogyatékos személy életpályáját (Krémer, 2009).

A fogyatékosság megélése nagyban függ attól, hogy a társadalom hogyan határozza meg a fogyatékosság fogalmát, és kit tekint fogyatékkal élönek, és hogy mindezt nem személyes szerencsétlenségként, karitatív lehetőségként, vagy csupán orvosi feladatként definiálja. A fogyatékosságot az egyén másként, kirekesztettként, különbként éli meg. A fogyatékosságot társadalmilag konstruált identitásként, valamint reprezentációs rendszerként fogja fel a társadalom, ezáltal a fogyatékos személy a társadalom részévé válik, így a hangsúly a hatalmi viszonyokon, a diszkriminációkon, az elnyomáson, és a társadalmi viszonyokon áll (Fogyatékosságtudományi fogalomtár, 2009).

A fogyatékosság egy változó fogalom, amely a fogyatékkal élők és az attitüdbeli, valamint a környezeti akadályok egyfajta kölcsönhatásának a következménye, amely révén a fogyatékos személy gátolva van a társadalomban való teljes, hatékony részvételben. A fogyatékkal élő személy állapota nem változtatható meg, nem szüntethető 
meg, nem gyógyítható, egy változatlan, örök állapot. Ezáltal válik a fogyatékos személy védtelenné, kiszolgáltatottá. Az ö helyzetében a „betegszerep”, valamint a „fogyatékos lét” egy egész életre szóló helyzet (Kálmán, Könczei, 2002).

\section{A társadalmi egyenlőtlenségek}

Az egyének szempontjából a szociálpolitika adott egyének helyzetét viszonyítja másokéhoz, a normákhoz, a szokásoshoz. A család szempontjából elsősorban a segélyezési rendszer a hiányok feltárását és a szükséglethiányok megállapítását a háztartások, családok helyzete alapján állapítják meg. A hátrányok enyhítése irányulhat ugyanakkor csoportokra is, például roma gyerekek iskolai programja, Tanoda program. De nagyobb közösséget is érinthet a támogatás rendszere, mint például bizonyos társadalom részeket, például a diákok vagy nyugdíjasok, kismamák részére nyújtott támogatások.

Az egyenlőtlenségek különfélék lehetnek, az ezeket korrigálni kívánó politikák igyekeznek ezeket enyhíteni.

A fogyatékos személyek esetében az egyik legalapvetőbb probléma a társadalomban való részvétel akadályozottsága, ennek érdekében születtek meg olyan alapelvek, melyek elősegíti ezen hátrányok minimalizálását.

Többek között az egyik legfontosabb az egyenlő bánásmód elve, mely szerint mindenki számára egyaránt biztosítani kell a hátrányos megkülönböztetéstől, magalázástól mentes bánásmódot. Az esélyegyenlőség egyfelöl egy törvény által garantált jogként müködik, mely a részvétel egyenlöségét hivatott biztosítani, másrészt egyre inkább jelenti mindemellett a gyengébb helyzetüek segítését, erősítését (Krémer, 2009).

A külvilág felől érkező elvárások és a fogyatékossággal járó állapot gondokat okozhat mind a szülők mind a szakemberek számára, hiszen a sérült személy értelmi és érzelmi szintje nincs szinkronban az életkorával, amely elsősorban az értelmileg sérült személyeknél jellemző, de megfigyelhetjük a fogyatékosság többi típusa esetén is. Az akadályozott személy ellátása, gondozása során ezt szinkronba kell hozni, ehhez szükséges a megfelelő támogatás, ahol egyenrangú partnerként kell, hogy kezeljük a sérült személyt. Az esélyegyenlőség megteremtéséhez szükségszerü, hogy számára megfelelö, hasznos munkát végezzen, hogy ugyanazokat a szolgáltatásokat vegye igénybe, mint bárki más (vásárlás, orvos, szociális szolgáltatások stb.). Ehhez elengedhetetlen a partnerségi viszony a segítők és szülők, valamint az ellátottak között (Zolnai, 2001).

Lehetővé kell tenni számára, hogy beleszólhasson saját életébe, hogy döntéseket hozhasson, hogy jövőbeni terveket szőhessen, célokat tüzzön ki maga elé. A sérült emberek számára is lehetőséget kell biztosítani a munkahelyi szerepek, csoportszerepek, társas szerepek megismeréséhez.

\section{A szolgáltatástípusok jellemzői}

A szociális kihívások kezelésére létrehozott ellátórendszer bár országonként eltérő, azonban alapjaiban azonosságot mutat. A személyes segítséget nyújtó szolgáltatások 
tekintetében sok hasonlóságot találunk a különböző országok ellátórendszerei tekintetében, ezek típusai a következők:

- gyermekgondozási intézmények, melyek napközbeni ellátást biztosítanak (bölcsődék, óvodák, családi gyermekfelügyelet),

- gyermekotthonok, nevelőszülöi ellátás, helyettes szülők,

- javító-nevelö intézetek,

- $\quad$ saját otthonban biztosított ellátások önmaguk ellátására csak részben képes személyek részére (idősek, fogyatékkal élők, pszichiátriai betegek), házi segítségnyújtás, jelzőrendszeres házi segítségnyújtás,

- nappali ellátást biztosító intézmények (nappali ellátás),

- ápoló-gondozó intézmények a teljes ellátást igénylő kliensek részére.

A szociális ellátások tekintetében alapvető fontosságú, hogy minden személy az állapotának megfelelő - személyre szabott-átmeneti, vagy tartós gondozást vehesse igénybe. A szociális munka alapvető elveit alapul véve sem a túl- sem pedig az alulgondozás nem megengedhető a kliensek ellátása tekintetében (Kozma, 1998) (1993. III. törvény).

\section{A szakosított ellátások}

Az önmaguk ellátására nem, vagy részben képes, illetve teljes mértékben ellátásra szoruló személyek ellátására születtek meg az ún bentlakásos intézmények, mely teljes körü szolgáltatást biztosítanak a kliensek számára. Az enyhébb fokban sérült személy esetén igénybe vehető ellátás típus a rehabilitációs intézményrendszer, mely elösegíti a későbbiekben minél önállóbb életvitel folytatását. Amennyiben az ellátásra csak ideiglenesen van szükség, akkor az átmeneti intézmény biztosít ellátást. A teljes körü, élethosszig tartó ellátásra szakosodott intézménytípus továbbá a lakóotthon, mely kis létszámával (maximum 14 fö) családias légkört és életvitelt biztosít a kliensek számára (1993. évi III. törvény).

Amennyiben a gazdasági szempontokat vesszük figyelembe a nagy létszámú (akár 4-500 fős) intézmények fenntarthatósága az infrastruktúra, a különböző költségek, a munkaerő kihasználtsága szempontjából előnyösnek tekinthető, azonban ez a szociális munka alapelveivel teljes mértékben szemben áll. Az elmúlt évek során már több intézmény kezdeményezte az ún kitagolási program keretében a nagy létszámú intézmények ellátotti számának csökkentését.

A létszámadatokat tekintve a népszámlálási adatok szerint 2013-ban az ápoló-gondozó intézmények átlagos befogadó képessége 82 fó volt, és minden harmadik intézmény 100 fó felett látta el a fogyatékos személyeket. Ebből adódóan az ellátottak több mint fele kénytelen több mint 100 emberrel megosztani életét, mindennapjait. Ebben az esetben mindenképpen érdemes elgondolkodni az ellátás minőségét illetően, többek között például a magánszférához való jog szempontjából. Két dolog szembenállását figyelhetjük meg a gazdaságosság, vagy finanszírozhatóság szemben az alapvető emberi jogokkal.

A fenntartó szervezeti formája és az ellátotti létszám között összefüggés figyelhető meg atekintetben, hogy a legmagasabb férőhelyszámmal az állami és önkormányzati 
intézmények rendelkeznek. A legalacsonyabb férőhelyszám pedig a nonprofit szférában található. A férőhely vizsgálatok alapján feltételezhető, hogy míg az állam által biztosított ellátás leginkább „csak” magának az ellátásnak a biztosítására figyel, addig a civil szervezetek - sokszor erőn felül is - igyekeznek a minőség biztosítására is figyelmet fordítani.

A kapacitásokat tekintve 2013-ban 16,5 ezer fó ellátására volt elegendő. A teljes népesség arányt tekintve (450 ezer fö) ez összesen 0,4 \%-os ellátottságot biztosítana (Bass L, 2004).

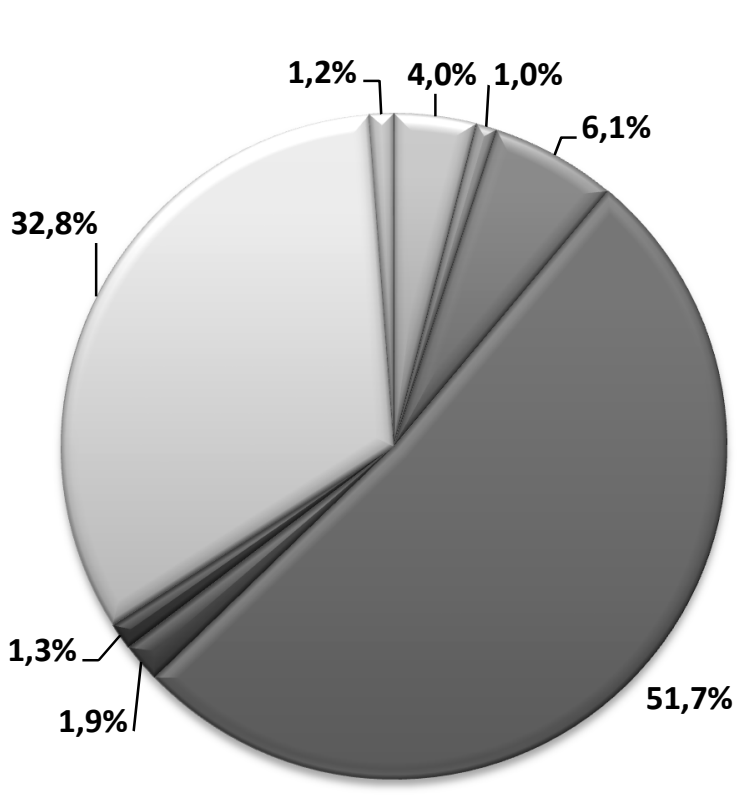

$\square$ Látás sérültek (4,0\%)

$\square$ Hallássérültek (1,0\%)

$\square$ Mozgáskorlátozott $(6,1 \%)$

๑Értelmileg akadályozott

$(51,7 \%)$

Q Kommunikációban számottevően korlátozott

$(1,9 \%)$

口Autizmussal élő (1,3\%)

$\square$ Súlyosan halmozottan

fogyatékos $(32,8 \%)$

$\square$ Nincs fogyatékossága $(1,2 \%)$

(Forrás: saját szerkesztés, 2011. évi Népszámlálási adatok)

1. ábra. A tartós bentlakásos otthonokban ellátott fogyatékosok megoszlása a fogyatékosság típusa szerint, 2013.

A családok által leginkább elfogadott intézménytípus a lakóotthon, ugyanakkor a szülők számára is nyilvánvalóan kevés férőhellyel, esetlegesen a lakóhelyüktől igen távol találhatnak ilyen típusú szolgáltatást. A lakóotthonok földrajzi eloszlása igen kedvezőtlen, mely szerint Budapest rendelkezik a legkevesebb, Vas megye pedig a legtöbb férőhellyel. Továbbá a férőhelyek több mint fele községekben található. Az otthonok elhelyezkedése megnehezíti a családdal való kapcsolattartást és elösegíti a szegregálódást. 
Az elmúlt években számos tanulmány rávilágít arra, hogy a nagy létszámú intézmények elősegítik az elszigetelődést, az önállóság elvesztését, a családdal való kapcsolattartás megszünését. Ez tulajdonképpen a minimálisra csökkenti a fogyatékos személyek társadalomban való részvételét, amely elősegíthetné az elöítéletesség csökkenését (Kozma, 2009).

A fogyatékos személyeket nevelő családok nagy százaléka számol be elszigetelödésröl, elmagányosodásról, arról, hogy az életük a fogyatékos személy körül forog. Talán ennek a helyzetnek a megváltoztatására szolgálna a sokkal szélesebb körü integrációs tevékenység - a fogyatékkal élők körében -, valamint a szemléletváltozás elősegítése szempontjából érzékenyítő programok nagyobb arányú megvalósítása, melyre az utóbbi években több kísérleti program is született- lásd például a „Mindenkinek becsengettek" projektet. Továbbá az egymás, illetve a másság megismerése és elfogadása szempontjából zajló programok nyilvános népszerüsítése.

\section{Következtetések}

Az előzőekben röviden összefoglalt helyzet, mely vázolja a felnőtt korú fogyatékossággal élő személyek lehetőségeit a mindennapokban késztetett arra, hogy megvizsgáljam a rendelkezésre álló források - intézmények - állapotát, müködését, elsősorban kihangsúlyozva és alapul véve a normalizációs elvek gyakorlati megvalósulását.

A vizsgálat jövőbeni fó célja az esetleges különbözőségek - fenntartói, szolgáltatási - feltárása, és ezek elemzése annak érdekében, hogy az intézményi keretek között élő sérült személyek jogai ne csorbuljanak a rendszer sajátságos szabályozási hátteréből fakadóan. Fontosnak tartom továbbá, hogy a kutatás eredményeit felhasználjuk a gyakorlatban mind a fenntartók, mind a szakemberek, valamint a szülők támogatása érdekében. Ugyanakkor mindemellett nem elhanyagolható szempont a társadalmi szemlélet formálás hangsúlyozása sem.

\section{Irodalomjegyzék}

1. Bass L. (szerk.) (2008): „Amit tudunk és amit nem ... az értelmi fogyatékos emberek helyzetéről Magyarországon.Kézenfogva Alapítvány, Budapest.

2. Bonoli G. (2001): Political institutions, veto points and the process of welfarestate adaptation. In:Nyilas Mihály (2009) (szerk) A jóléti állam a 21. században,Budapest.

3. Csoba J. (2017): Gondoskodó állam, aktiváló állam, befektető állam, SOCIO.hu, 2017.1.

4. Demeter M. (1998): A tartós bentlakást biztosító állami (önkormányzati) fenntartású intézetek és a bennük élő értelmi fogyatékos felnőttek jellemzői -különös tekintettel az eddigi és a folyamatban lévő 52 Központi Statisztikai Hivatal Népszámlálás, 2011 kitagolási kezdeményezésekre. In: A függőségtől az autonómiáig. Kézenfogva Alapítvány, Budapest. 
5. Esping-Andersen (1990): The three worlds of welfare capitalism. Princeton, New Jersey: Princerton University Press.

6. Fogyatékosságtudományi tanulmányok (2009): A fogyatékosság definíciói Európában: Összehasonlító elemzés. Második, javított kiadás. Elérhető: http://mek.oszk.hu/09400/09455/09455.pdf (letöltés 2017.12.11.)

7. Kálmán Zs., Könczei Gy. 2002. A Taigetosztól az esélyegyenlőségig, Budapest: Osiris.

8. Kozma Á. (2009): Az intézetben élő értelmi fogyatékos emberek helyzete. In: Bass László (szerk.): Amit tudunk, és amit nem ... az értelmi fogyatékos emberek helyzetéről Magyarországon. Kézenfogva Alapítvány, Budapest.

9. Kozma J. (szerk) (1998): Kézikönyv szociális munkásoknak, Szociális Szakmai Szövetség, Budapest.

10. Kozma J.(2001): Szociális diagnózis, Esély, 2001/3.

11. Krémer B. (2009): Bevezetés a szociálpolitikába, Napvilág Kiadó, Budapest.

12. Mead,L. (1986):Beyond Entitlemend. The Social Obligations os Citizenship. New York, London: Free Press.

13. Zolnai E. (2001):a. Értelmet az életüknek... In Falvai R.: Értelmet az életüknek... Fészek szakmai füzetek 2. Budapest, Kézenfogva Alapítvány.

\section{Jogszabályok:}

1. 1993. évi III. a szociális ellátásokról és igazgatásról

2. 1998. évi XXVI. törvény a fogyatékos személyek jogairól és esélyegyenlőségük biztosításáról 